\title{
Investigating the position and effect of the Chamber of Commerce, Industries, Mining and Agriculture in the economy of Kashan city
}

\author{
Saeed Farahi ${ }^{1}$ and Mohsen Khadem ${ }^{2 *}$ \\ 1,2 Department of Management, Naragh Branch, Islamic Azad University, Iran \\ Email: saeid_f51@yahoo.com, Mkhadem@iau-naragh.ac.ir
}

\begin{abstract}
The purpose of this study is to investigate the position and effect of the Chamber of Commerce, Industries, Mining and Agriculture on the economy of Kashan city. In this research, we use descriptive and survey methods to investigate and describe the general characteristics of respondents and inference that is calculated using sample values of the statistics and then, through estimating or testing the statistical hypothesis, generalizes the statistics to the parameters of society. The statistical population of this study was all real and legal members of the Chamber of Commerce in Kashan city (500 subjects) from among which the sample size is calculated to 220 using the Morgan table. Validity of the questionnaire was assessed through face validity and based on the opinion of some university professors and Cronbach's alpha test was used for the reliability of the questions in the questionnaire where the obtained coefficient is equal to 0.941 which indicates a very good relationship between the questionnaire's questions.

Three hypotheses were also suggested in this research, that there is a meaningful relationship between the activities of the Chamber of Commerce, the participation of the real and legal members of this organization and the satisfaction of its members with the activities of the Chamber of Commerce and Economic Development of the city. The obtained results indicated that all three factors affect the economic development of the city and have a meaningful relationship with each other. At first, the activities of the chamber of commerce, then the satisfaction of the real and legal members of the Chamber of Commerce of Kashan, and finally the participation of the real and legal members of the chamber of commerce, respectively, have the highest impact on the city economic development variable. (Eisenberg, 2009)
\end{abstract}

Keywords: Economic Development of the City, Chamber of Commerce, Members' Rights, Privatization

Introduction

Today, industry, mining, and commerce are known as three pillars of economic geometry of the countries. Any country that can manage and coordinate more and more effectively in this area, the people of that country will sure witness a significant growth in the economy.

Of course, many years ago, many countries have been working to coordinate these three parts by establishing an organization called the chamber of commerce. Now, many years pass the establishment of the Chamber of Commerce, Industries, Mines and Agriculture and its role in the above sectors can be important, constructive and effective.

In most developed countries, there is relatively modest interaction between the expansion of the private sector and the formation of commercial chambers, and free economic policies are the result of the interaction between the development of the private sector and the lack of government intervention in the economy. 
The chambers of commerce, as intermediary organizations between government and commerce, emerged at the same time as the emergence and development of a market-oriented economy and expanded rapidly. The position and function of the chambers of commerce in maintaining competitiveness and ordering the market-oriented economy system is such that it is necessary to study and gain a deeper understanding of the nature, functioning, history and evolution of it. (Chen, 2016)

One of the cities of Iran which is considered as the important economic areas in the country, is Kashan city. Kashan's economy has long been on a wide range of industries, agriculture, mines and trade. The handicraft carpet industry of Kashan has been a long time spoken in artistic, economic, exhibition and scientific circles. In addition, Kashan is one of the first Iranian cities hosting factorial industries.

Today, Kashan has become one of the industrial poles of the country with dozens of carpet factories and industries such as porcelain and melamine, tile, spinning and industrial tools.

In such a regional space, the Chamber of Commerce can play an important role in creating and sustaining economic activities. The Chamber of Commerce is a nonprofit institution with legal personality and financial independence. One of the characteristics of the commercial chambers is the regionality of their structure, because it is only in a certain environment that a chamber can provide the necessary initiatives to ensure and encourage direct contact between the chamber and its members. Also, the presence of the chamber will allow for definite determination of regional features; otherwise, this feature may be overshadowed by the views of other large organizations. (Wang, 2017) Today, the goals of the chambers of commerce include providing growth and prosperity and developing the country's economy, exchanging ideas and expressing the opinions of industrial, commercial, agricultural and mineral managers. (Finkelstein, 2012)

The importance of the private sector in its decision-making and its active participation in the commercial chambers of developed countries has paved the way for the chambers to play a very active role in the economic and commercial development. (Franklin, 2009)

The Chamber of Commerce has a consultative role and, besides being responsible for the transfer of problems to other decision-making organs and authorities in the country, expresses the reactions of economic laws in society and attempts to establish it in order to facilitate and expedite the use of goods and services. (Dasí-Rodríguez, 2015)

Therefore, the implementation of government administrative reductions in order to realize developmental policies and the extension of the private sector requires active business chambers.

Providing facilities for economic growth and development of the country and expressing the opinions of managers of industrial, agricultural, commercial and other sectors are the most important duties of the Iranian Chamber of Commerce.

Services to members can be provided either directly or privately. These services are mainly focused on foreign trade, as well as related operations, such as credit documents, etc. Finally, the documents and reports from the chambers are gathered and reviewed by the board. If the performance is not aligned with the system of accreditation and standardization, the Board of Directors and its members will be dismissed. (Choi, 2009)

Research background 
So far, no research has been done on the subject of this research, and the necessity of this discussion has been observed among the regional studies of Kashan city. It is worth noting that the results of this research can also be exploited in the impact of other city chambers on the economy of their regions.

\section{Methodology}

\section{Descriptive findings of the study}

What can be obtained by referring to the results of the descriptive section of the research are: - In the sample under study, $90.9 \%$ of the respondents are male and $9.1 \%$ are female, $15.9 \%$ of the respondents age between 20 to $30,41.8 \%$ age between 31 to $40,22.7 \%$ age 41 to 50 and $19.5 \%$ age over $51.41 .4 \%$ of the respondents had a diploma, $14.5 \%$ had associate degree, $26.8 \%$ had bachelor degree, $13.6 \%$ of had MA degree and 3.6\% had a Ph.D. degree. (Mobley, 2017)

- In the sample under study, $17.7 \%$ of the respondents had a work experience of less than 5 years and $25.9 \%$ had a work experience between 6 to 10 years, $14.5 \%$ had a work experience of $11-15$ years and $23.2 \%$ had a work experience between 16 and 20 years and $18.6 \%$ had a work experience of over 21 years.

Regarding the activity of the respondents, $66.8 \%$ are busy in the field of production, $25.9 \%$ are busy in the field of commerce, $6.4 \%$ are busy in the field of services and $0.9 \%$ are busy in other fields.

The activity range of respondents is respectively $27.7 \%$ internal range, $3.6 \%$ the external range, and $68.6 \%$ in both the internal and external range.

In the studied sample, 206 respondents are members of the Chamber of Commerce, and 14 have not yet joined the Chamber of Commerce.

In the studied sample of the members of the Chamber of Commerce, 50.5\% have a membership of less than 5 years, $21.8 \%$ between 6 to 10 years, $12.3 \%$ between 11 to 15 years, $5.5 \%$ between 16 to 20 years, and $3.6 \%$ have over 21 years of membership in the Chamber of Commerce. In the studied sample, $39.1 \%$ of the respondents chose the option "very high" in response to the business chamber's activities, and only $2.7 \%$ chose of the option "very poor".

Considering the average which is 3.94, the respondents evaluate the effects of the activity of Chamber of Commerce as positive.

In the studied sample, $35.3 \%$ of the respondents chose the option "average" in response to the participation of real and legal members of the Chamber of Commerce and only $2.7 \%$ chose the option "very poor". Considering the average which is 3.25 , the respondents evaluate the effects of the activities of Chamber of Commerce as positive.

In the studied sample, $39.1 \%$ of the respondents chose the option "high" in response to the satisfaction of real and legal members of the Chamber of Commerce and only $1.8 \%$ chose the option "very poor"

According to the average which is 4.903 , the respondents evaluate the effects of the activities of Chamber of Commerce as positive. 
First hypothesis: There is a meaningful relationship between the activities of the Chamber of Commerce in Kashan and the economic development of the city.

Table 1. Correlation coefficient between the activities of the Chamber of Commerce and Economic Development

\begin{tabular}{|l|l|l|l|l|}
\hline & $\begin{array}{l}\text { Correlation } \\
\text { coefficient }\end{array}$ & $\begin{array}{l}\text { Level of } \\
\text { significance }\end{array}$ & Number & Result \\
\cline { 2 - 5 } & $0.757 * *$ & 0.000 & 220 & $\begin{array}{l}\text { There is a direct } \\
\text { and strong } \\
\text { relationship }\end{array}$ \\
\hline
\end{tabular}

The findings of the above table indicated that the significance level of the test was the existence of the relationship between "activities of the chamber of commerce" and "economic development of the city" less than $\alpha=0.05$, so with $95 \%$ confidence the existence of the relationship between "business chamber activities" and "economic development of the city" is accepted and this test is significant. The correlation between these two variables is direct and strong $(r=0.777)$, that is, with the improvement of the "Chamber of Commerce activities", the rate of "city economic development" increases. (Levesque, 2016)

Second hypothesis: There is a significant relationship between the participation of legal and factual members of Kashan Chamber of Commerce in the activities of this institution and its economic development.

Table 2. Correlation coefficient between the participation of real and legal members of the Chamber of Commerce on economic development

\begin{tabular}{|l|l|l|l|l|}
\hline & $\begin{array}{l}\text { Correlation } \\
\text { coefficient }\end{array}$ & $\begin{array}{l}\text { Level of } \\
\text { significance }\end{array}$ & Number & Result \\
\cline { 2 - 5 } & $0.830^{* *}$ & 0.000 & 220 & $\begin{array}{l}\text { There is a direct } \\
\text { and strong } \\
\text { relationship }\end{array}$ \\
\hline
\end{tabular}

The findings of the above table indicated that the significance level of the test was the existence of the relationship between "participation of the members of the chamber of commerce" and "economic development of the city" less than $\alpha=0.05$, so with $95 \%$ confidence the existence of the relationship between " membership of the chamber of commerce " and "economic development of the city" is accepted and this test is significant. The correlation between these two variables is direct and strong $(\mathrm{r}=0.830)$, that is, with the improvement of the "participation of the members of the chamber of commerce", the rate of "economic development of the city" increases. (Chen N. T.-R., 2017)

Third hypothesis: There is a significant relationship between the satisfaction of real and members of the Chamber of Commerce of Kashan from the activities of this institution and the economic development of this city.

Table 3. Correlation coefficient between satisfaction of real and legal members of the Chamber of Commerce on economic development. 


\begin{tabular}{|l|l|l|l|l|}
\hline & $\begin{array}{l}\text { Correlation } \\
\text { coefficient }\end{array}$ & $\begin{array}{l}\text { Level of } \\
\text { significance }\end{array}$ & Number & Result \\
\cline { 2 - 4 } & $0.738^{* *}$ & 0.000 & 220 & $\begin{array}{l}\text { There is a direct } \\
\text { and strong } \\
\text { relationship }\end{array}$ \\
\hline
\end{tabular}

The results of the above table indicated that the significance level of the testing the relationship between "satisfaction of members of the chamber of commerce" and "economic development of the city" was less than $\alpha=0.05$, so with $95 \%$ confidence, the existence of the relationship between "satisfaction of members of the chamber of commerce" with "economic development of the city" is accepted and this test is meaningful. The correlation between these two variables is direct and strong $(\mathrm{r}=0.738)$, which means that by improving "the economic development of the city" the "satisfaction of members of the chamber of commerce" will increase. (Kleynhans, 2017)

The coefficients indicate the regression effect of each independent variable on the dependent variable (economic development of the city), where actually the interpretation regression is based on the coefficient of Beta. So, firstly, considering that the t-test value for all three variables is significant at the level of $p<0.05$, the effect of all three variables on the economic development of the city is confirmed, and second, the variables of the chamber of commerce, the satisfaction of the members of the chamber of commerce and the participation of the members of the chamber of commerce Respectively, have the highest impact of regression on the economic development variable of the city.

3. Investigating the role of descriptive variables

The gender of respondents does not affect their responses and therefore the research variables ( $>0.05$ ). In other words, male and female clients are in agreement with the research variables. (Gadar, 2009)

The respondents' age group does not affect their response and therefore the research variables ( $\mathrm{p}<0.05$ ). In other words, people with different age groups have different ideas in their responses to all four variables. For example, in case of the variable of economic development of the city, people aged 51 and above and in the variable of the activities of the chamber of commerce, the age group of 20 to 30 years have gained higher rank than other age groups.

Respondents' education affects their response and therefore the research variables $(\mathrm{p}<0.05)$. In other words, people with different degrees have different ideas in answering to each of the four variables. As an example, the variables of economic development in the city, people with Ph.D. education and in the variable of participation of the members of the chamber of commerce, people with a bachelor's degree have ranked higher than other groups. (Micallef, 2017)

The work experience of respondents has had an impact on their response ( $p<0.05)$. In other words, people with different work experience have different opinions in responding to these variables. In other words, people with different work experiences have different opinions in responding in responding all the four variables. For example, in case of the variable of economic development, people with a work experience of 21 years and above and in the variable of activities of the chamber of commerce, people with a work experience of less than 5 years have achieved higher rank than other groups. 
The field of activity of respondents has an impact on their responses and therefore research variables $(\mathrm{p}<0.05)$. In other words, people with different backgrounds have different ideas in their response to these three variables. As an example, about the economic development of the city, the other group and about the participation of the members of the Chamber of Commerce, the Chamber of Commerce have been higher than other groups.

Conclusion

Based on the findings of the research, it was determined that the Chamber of Commerce in Kashan city has an impact on the economic development of this city, which is evident with regard to the subjects discussed in this study. The activities of the Chamber of Commerce in the field of privatization, manufacturing, commercial and services are quite evident. In the field of participation of the real and legal members of this institution, the activities of this chamber have been well done and, finally, the satisfaction of the members of the Chamber of Commerce of this institution represents the good and effective activities of this room in the economic development of this city.

\section{References}

Akbari, S. (2015), The article of "The executive and legal mechanisms of empowerment of the private sector"

Regulations of the Chamber of Commerce, Industries and Mines of the Islamic Republic of Iran

Torabi Farasani, S. (2013), From the Chamber of Traders to the Chamber of Iran, Tehran, Museum Library Publications.

Hafez Nia, M., 2005, "An Introduction to the Methodology in the Humanities," SAMT Publications, Tehran.

Heshmati Mola'i, H., (2009) Pathology of the position and performance of the Chamber of Commerce in the development of the role of the private sector in foreign trade, Journal of Parliament and Strategy, $16^{\text {th }}$ year, No. 61.

Nasim News Agency - 3.2.2015

Newspaper of World Economy, No. 3413, 3432, 2302

Shirinkam, F., Farjamnia, I. (2014), The story of fifty Iranian economic activists, Tehran, Farhang-e Saba Publications.

Qazi, J., (2014), The developments of the Chamber of Commerce of Kashan, Quality Publications, First Edition. Tehran.

Law of the Chamber of Commerce of Iran, adopted in 1994.

Monthly Journal of the Chamber of Commerce, (2009), No. 137.

Articles and Researches of Tehran Chamber of Commerce, Strategic Planning of Tehran Chamber of Commerce (2015)

Monthly Journal of Tadbir, No. 154, March 2004.

Monthly Journal of Tadbir, No. 170, June 2008.

Weekly Journal of Chamber of Commerce, (2007), No. 130.

Akhlaqi Faiz, M. et al., (2014), Requirements for the Development of the Private Sector in the Iranian Economy, Report on Economic Freedom and Improving Business Space

Freddar D. (2000), Strategic Management, Translated by Ali Parsaeian and Mohammad A'arabi, Cultural Research Center, Tehran 
Chen, N. T.-R. (2017). Causing ripples in local power relations: The meso-level influence of a hyperlocal news website. Journalism Studies, 18(6), 710-731.

Chen, Z. G. (2016). Developing an online database of experts for the Worcester Regional Chamber of Commerce.

Choi, S. J. (2009). Judicial evaluations and information forcing: Ranking state high courts and their judges. Duke Law Journal, 1313-1381.

Dasí-Rodríguez, S. \&.-d.-V. (2015). Seeking partners in international alliances: The influence of cultural factors. Journal of Business Research, 68(7), 1522-1526.

Eisenberg, T. (2009). US Chamber of Commerce liability survey: Inaccurate, unfair, and bad for business. Journal of Empirical Legal Studies, 6(4), 969-1002.

Finkelstein, E. A. (2012). Obesity and severe obesity forecasts through 2030. American journal of preventive medicine, 42(6), 563-570.

Franklin, D. L. (2009). What kind of business-friendly court? Explaining the Chamber of Commerce's success at the Roberts Court.

Gadar, K. \&. (2009). The influence of personality and socio-economic factors on female entrepreneurship motivations in Malaysia. International review of business research papers 5(1), 149-162.

Kleynhans, E. P. (2017). The influence of space on business confidence. AfricaGrowth Agenda, 2017(Jan/Mar 2017, 14-17.

Levesque, V. R. (2016). Planning for sustainability in small municipalities: The influence of interest groups, growth patterns, and institutional characteristics. Journal of Planning Education and Research, 0739456X16655601.

Micallef, M. (2017). Role and Current Status of IFRS in the Completion of National Accounting Rules-Evidence from Malta. Accounting in Europe, 1--6.

Mobley, C. S. (2017). The Influence of Career-Focused Education on Student Career Planning and Development: A Comparison of CTE and Non-CTE Students. Career and Technical Education Research, 42(1), 57-75.

Wang, H. (2017). Origin and network: examining the influence of non-local chambers of commerce in the Chinese local policy process. Doctoral dissertation. University of Glasgow. 